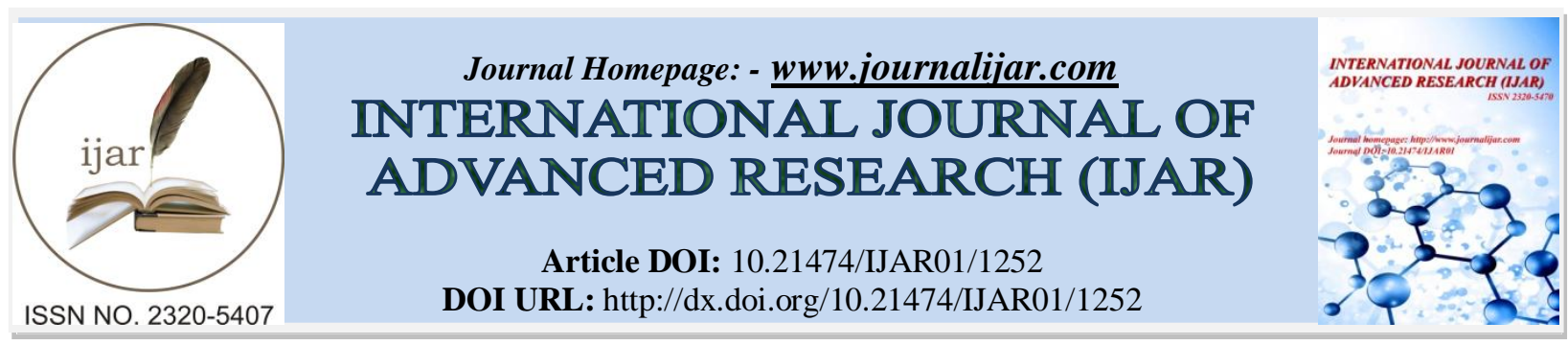

RESEARCH ARTICLE

\title{
EFFECT OF TRACTORIZATION ON REDUCTION IN NATURAL POPULATION OF PROSOPIS CINERARIA (L.) IN AGRO ECOSYSTEM OF THAR DESERT.
}

\author{
Shiwani Bhatnagar, Sangeeta Singh, Ameen Ullah Khan, Bundesh Kumar, Parveen Goran, S. I. Ahmed, \\ K. K. Srivastav and T.S Rathore.
}

Forest Protection Division, Arid Forest Research Institute, New Pali Raod, Jodhpur.

\section{Manuscript Info}

Manuscript History

Received: 12 June 2016

Final Accepted: 19 July 2016

Published: August 2016

Key words:-

Natural regeneration, Khejri, tractor ploughing

\section{Abstract}

A study on the effect of tractor ploughing during 2013-14 was conducted at North western districts of Rajasthan viz., Churu, Sikar, Jhunjhunu and Nagaur. It was observed that naturally regenerated Khejri seedlings usually get destroyed during tractor ploughing in the farmers fields. As per the observation average numbers of new Khejri seedlings in 30x $30 \mathrm{~m}^{2}$ plot were more in Gochar land /undulated lands $(0.38 \pm 0.06$ per plot $)$ as compared to tractor ploughed agriculture land in which average number of new Khejri seedlings was recorded $0.04 \pm 0.02$ per plot. It seems that buttressing of Khejri population is very difficult due to implementation of advanced changes in Indian agroecosystem. Also the population of the old existing Khejri trees has been reduced during past few decades due to biotic and abiotic stresses. This calls for protection of naturally regenerated Khejri seedlings as these can help in increasing the density of Khejri trees in Rajasthan.

Copy Right, IJAR, 2016,. All rights reserved.

\section{Introduction:-}

Prosopis cineraria belonging to the family Leguminosae and subfamily Mimosoideae is a multipurpose tree species that provides fodder, fuel, food, timber, and shade. $P$. cineraria effectively stabilize sand dunes and can withstand periodic burial (Gates and Brown 1988). Farmers in arid and semi-arid regions of India and Pakistan have long believed it to increase soil fertility in crop fields. Mann and Shankarnarayan (1980) observed increase in yields of sorghum or millet when grown under $P$. cineraria, as a result of higher organic matter content, total nitrogen, available phosphorus, soluble calcium, and lower pH. Singh et al., (2007) indicated greater benefits of $P$. cineraria tree integrated at optimum density through tree produced and synergistic effects on the annual crops.

Through ages the practice to cultivate trees and agricultural crops in intimate combination is followed which help to assist the ordinary farmers to increase farm income and to conserve the environment. Khejri is endemic to the hot deserts of India and is considered to be an essential component of the agroforestry land use system with enormous economic and cultural values to the people of Rajasthan. But the population of Khejri, a priority tree and life line of Arid ecosystem, is rapidly declining due biotic factors (root rot fungus Ganoderma lucidum and root borer, Acanthophorous serraticornis) (Singh et al., 2012) and abiotic factors viz, over exploitation of ground water by way of tube wells, low rain fall over the years, consequent low ground water charging and change in agricultural 
practices by increased use of tractors and mechanized cultivation, resulting in harms to standing trees roots and seedlings (Ahmed et al., 2004). Increasing land fragmentation and high demand for wood fuel by the farmers are some other factors aggravating the problems.

Tractors are used to prepare farmlands for planting agricultural crops, which are thought to reduce greatly the survivability of young trees (Poudyal, 2009). The negative effect of tractor ploughing on shea regeneration is reported too by Lovett and Haq (2000) in Bole, in the Northern Region of Ghana. Sharma (2003) accounted that increasing area of cropping on marginal lands is causing desertification which is further accelerating by increasing use of tractor.

The importance of Khejri trees to the households (income from these trees) makes it still more important to protect the naturally regenerated Khejri trees in the farmers field. Therefore the present study was conducted to elucidate the effect of tractor ploughing on the naturally regenerated of Khejri (Prosopis cineraria) trees in Rajasthan.

\section{Material and Methods:-}

To work out the effect of mechanical ploughing, periodical observations were recorded in gochar land, undulated lands and tractor ploughed farmers field in four districts of Rajasthan (Nagaur, Sikar, Jhunjhunu and Churu). Three plots of the dimension $30 \times 30 \mathrm{~m}^{2}$ at each site were laid out and data on the number of Khejri trees, number of trees other than Khejri and number of new Khejri seedlings were recorded.

\section{Result and Discussion:-}

Mechanical ploughing is used to till the soil or plough the field. This can be cost effective, especially as large areas can be covered quickly. Cultivation by tractor has removed the limitation of draught power. Earlier the number of draught animals determined the area that was to be cultivated and since land was not the limitation, the farmer had nothing to lose by saving the trees. Now land has become the limiting factor. Also, it is not possible for tractor operator to see and avoid small shrubs, young seedling etc. (Jhunjhunwala, 2005).

During field preparation for sowing of a crop the roots of standing trees as well as young naturally regenerated Khejri seedlings gets severely damaged or killed out rightly. It was observed that except in one or two ploughed field wherein, farmer has given special attention to protect the new saplings during ploughing, no fresh seedlings were capable to grow further in the tractor ploughed fields. Thus it proves that the natural regeneration is severely affected with the use of mechanical ploughing though it does not have any direct impact on the mortality of trees. Whereas, in Gochar and undulated lands where tractor ploughing was not used, naturally regenerated seedlings were frequently been observed. As such it can be assessed that tractorization do not play direct role in tree mortality but reduces the population of Khejri trees by damaging its new seedlings.

As per the observation the average number of Khejri trees was $2.42 \pm 0.21$ per plot in tractor ploughed land and $2.75 \pm 0.25$ per plot in Gochar/ undulated land where the land is left untilled. Average number of trees other than Khejri was $0.67 \pm 0.28$ per plot in tractor ploughed land and $1.13 \pm 0.28$ in Gochar/ undulated land. Average numbers of newly engendered Khejri seedlings were more in Gochar land /undulated lands ( $0.38 \pm 0.06$ per plot $)$ as compared to tractor ploughed land in which average number was $0.04 \pm 0.02$ per plot (Table 1). Therefore, it seems utmost important to take care while ploughing the field in order to minimize the damage caused to the newly grown seedlings as well as to protect the damage caused to the rootlets of mature Khejri trees. The tree has many sensitive surface roots that get damaged during ploughing which thus retards the growth of the trees. 
Table 1:- The effect of tractorization on the natural regenerations of Khejri (Prosopis cineraria) at various sites in Rajasthan.

\begin{tabular}{|c|c|c|c|c|c|c|}
\hline \multirow{2}{*}{ Districts } & \multicolumn{2}{|c|}{$\begin{array}{c}\text { Average Number of } \\
\text { Khejri trees }\end{array}$} & \multicolumn{2}{c|}{$\begin{array}{c}\text { Average Number of other } \\
\text { trees }\end{array}$} & \multicolumn{2}{c|}{$\begin{array}{c}\text { Average Number of new } \\
\text { regenerated Khejri trees }\end{array}$} \\
\cline { 2 - 7 } & TPL & UL/GL & TPL & UL/GL & TPL & UL/GL \\
\hline Sikar & 2.67 & 3.33 & 1.2 & 1.6 & 0.00 & 0.53 \\
& \pm & \pm & \pm & \pm & & \pm \\
& 0.25 & 0.16 & 0.20 & 0.25 & & 0.17 \\
\hline Churu & 2.67 & 2.93 & 1.07 & 0.8 & 0.07 & 0.33 \\
& \pm & \pm & \pm & \pm & \pm & \pm \\
& 0.21 & 0.25 & 0.27 & 0.22 & 0.07 & 0.13 \\
\hline Jhunjhunu & 2.53 & 2.13 & 0.33 & 0.53 & 0.07 & 0.40 \\
& \pm & \pm & \pm & \pm & \pm & \pm \\
& 0.22 & 0.24 & 0.16 & 0.19 & 0.07 & 0.16 \\
\hline Nagaur & 1.80 & 2.60 & 0.07 & 1.60 & 0.00 & 0.27 \\
& \pm & \pm & \pm & \pm & & \pm \\
Mean \pm & 0.24 & 0.27 & 0.07 & 0.27 & & 0.12 \\
\hline Standard error & 2.42 & 2.75 & 0.67 & 1.13 & 0.04 & 0.38 \\
& \pm & \pm & \pm & \pm & \pm & \pm \\
& 0.21 & 0.25 & 0.28 & 0.28 & 0.02 & 0.06 \\
\hline
\end{tabular}

Note: $\pm=$ Standard error, TPL $=$ Tractor ploughed land, UL=Undulated land, GL=Gochar land

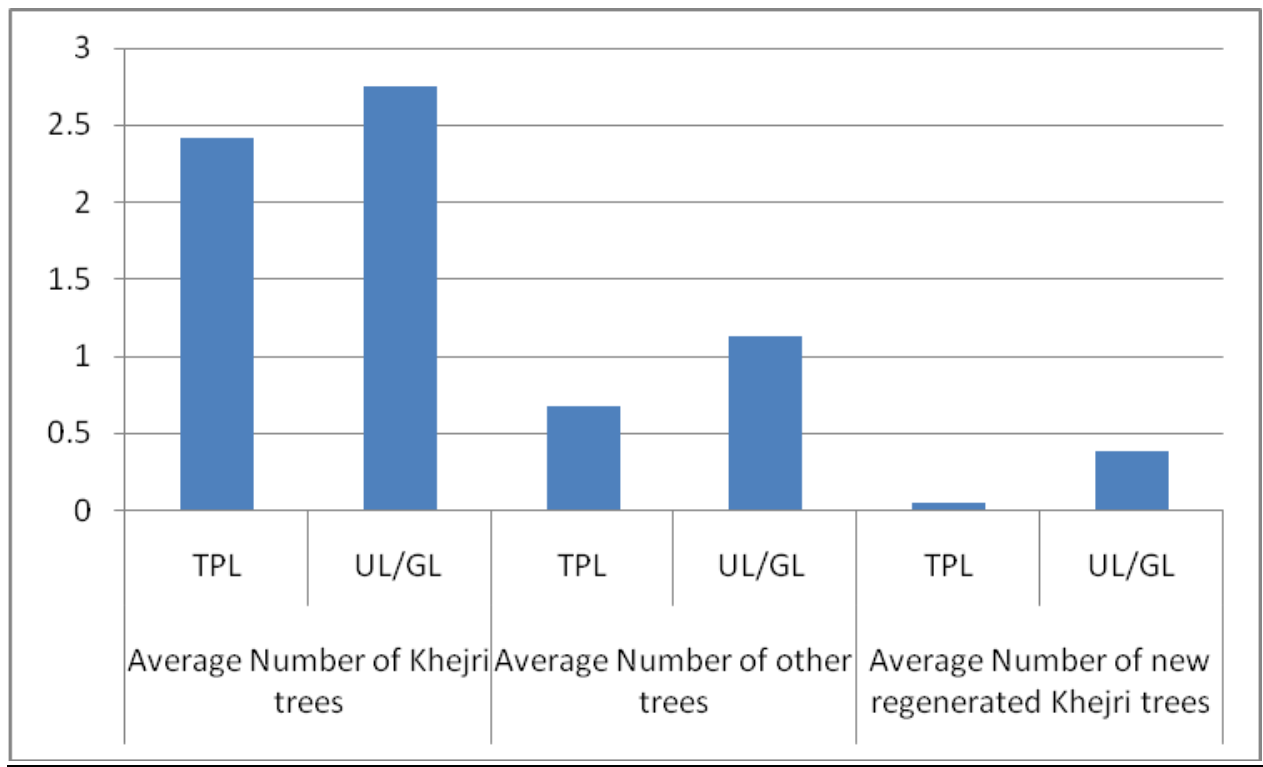

Fig 1:- The effect of tractorization on the natural regenerations of Khejri (Average of all four district).

Chaudhry (2011) reported that previously camels or oxen were used for ploughing the fields and farmers took special care in protecting roots of trees and new saplings of P.cineraria. Now with the advancement in agricultural practices, the old practices have become obsolete, which ultimately is not in favour of overall growth and health of fragile desert ecosystem. Mechanized field operations (use of tractors) not only increase soil erosion but also reduce the naturally regenerated population of various useful species (Jodha, 1997). Alexandre et al., (2007) observed that ploughing substantially reduced the density of naturally established stems.

Present investigation clearly reveals a serious deficiency in the level of natural regeneration of Khejri trees in mechanically ploughed agricultural fields (Fig 1). Albeit the pressure on land, biotic and abiotic factors affects the densities of these trees but the absence of strong incentives to care for the trees seems to be compounding the problem, especially in its natural regeneration. Khejri trees provides a significant contribution to the household income, in addition to the products such as fuel wood for local energy needs, thus providing enough incentives to protect these trees. Although the level of regeneration seems lower, however, helping farmers to understand the need 
for a healthy population of young trees to replace old and dying ones will certainly save the new regenerated Khejri seedlings. Farmers are to be made aware and be encouraged for planting, protecting, caring for and managing Khejri, the most important indigenous trees which have potential for off-farm income generation in these areas.

\section{Conclusion:-}

Present study was conducted to generate data on effect of tractorization on the reduction in natural regeneration of Khejri trees in arid and semi arid ecosystem. The natural regeneration of Khejri is very difficult due to modernization of agricultural implements (tractor ploughing), hence, the economy of farmers depend upon existing trees on their field. In the recent past, the mortality of Khejri trees due to frequent attack of disease and insect pest (Ganoderma and Acanthophorous serraticornis) has created a major problem in Rajasthan and therefore density of Khejri trees are decreasing day by day. Moreover, the regenerated seedlings of Khejri get damage due to mechanical operation in the field, thereby, reducing possibility of filling the gaps in the field. If trees regenerate naturally in anthropogenically impacted systems, this should be managed as an efficient and cheap way to restore the trees population. But the damage to juvenile regenerated seedlings (saplings), due to mechanical operations in the field, bar the way to success of natural regeneration of trees, that lead to create a bare land and calls for crying need to replant the fresh saplings, which is faced by high replanting operation cost. Therefore, to maintain the sustainability in nature, protection of naturally regenerated Khejri trees is de rigueur.

\section{References:-}

1. Alexandre B. Sampaio, Karen D. Holl and Aldicir Scario. Does Restoration Enhance Regeneration of Seasonal Deciduous Forests in Pastures in Central Brazil? Restoration Ecology. 2007; 15(3):462-471

2. Ahmed, S. I.; Chaudhuri, K. K.; Sharma, M. and Kumar, S. New Insect Pest Records of Khejri and Rohida from Rajasthan and their Possible Management Strategies. Indian forester. 2004; 130 (12): pp.1361-1374

3. Chaudhry, P. Prosopis cineraria (L) Druce: A life line tree species of the Thar Desert in danger. Journal of Biodiversity and Ecological Sciences. 2011; 1 (4): 289-293.

4. Jodha, N.S. Trends in tree management in arid land use in western Rajasthan. In: Farms trees and farmersresponse to agricultural intensification. (Eds J.E.M. Arnold and P.A. Dewees) Earth Scan Publishing, London. 1997; $43-64$.

5. Gates, P.J. and K Brown. Acacia tortilis and Prosopis cineraria: Leguminous trees for arid areas. Outlook on Agriculture.1988; 17:61-64.

6. Jhunjhunwala. Bharat .Traditional agricultural and water technologies of the Thar. Kalpaz publications, Delhi, 243pp.

7. Lovett, P.N., and Haq, N. (2000). Evidence for anthropic selection of the Sheanut tree (Vitellaria paradoxa). Agroforestry Systems. 2005; 48: 273-88

8. Mann, H.S. and K.A. Shankarnarayan. The role of Prosopis cineraria in an agropastoral system in Western Rajasthan. In Browse in Africa, edited by H.N LeHouerou, International Livestock Centre for Africa, Addis Ababa, Ethiopia.1980; pp. 437-442.

9. Poudyal, Mahesh. Tree Tenure in Agroforestry Parklands: Implications for the Management, Utilisation and Ecology of Shea and Locust Bean Trees in Northern Ghana PhD in Environment and Politics. University of York, Environment and Politics. 2009; 261p

10. Sharma, Arun K. Medicinal Plants Based Eco-Balanced Production System for Drylands. Desert Enviornment News (DEN) NEWS, CAZRI, Jodhpur. January -December 2003; 7 (1-4):5-8.

11. Singh, S.; Ahmed, S. I.; Srivastav, K. K.; Rathore, T. and Bhatnagar S. Status of Khejri mortality in North western regions of Rajasthan and its management. In: National seminar on forest health management, organized by IFGTB Coimbatore, March 21-22, 2012; pp.102.

12. Singh, G.; Mutha, S. Bala, N. Effect of tree density on productivity of a Prosopis cineraria agroforestry system in North Western. India Journal of Arid Environments. 2007; 70 (1); 152-163 